\title{
MEMBERSHIP REPORT.
}

For the Year Ending November 29, 1911

Paid up membership, Nov. 23, $1910 \ldots \ldots \ldots \ldots \ldots \ldots \ldots \ldots \ldots . \ldots 48$

Honorary membership, Nov. $23,1910 \ldots \ldots \ldots \ldots \ldots \ldots \ldots \ldots . \ldots$

Total membership, Nov. 23, $1910 \ldots \ldots \ldots \ldots \ldots \ldots \ldots \ldots \ldots . \overline{492}$

Delinquent, but left on list as per constitution $\ldots \ldots \ldots \ldots \ldots \ldots .83$

Total names on list, Nov. $23,1910 \ldots \ldots \ldots \ldots \ldots \ldots \ldots \ldots \ldots 75$

New members added during year $\ldots \ldots \ldots \ldots \ldots \ldots \ldots \ldots \ldots \ldots \ldots \ldots$

Resigned, deceased, or dropped for delinquency $\ldots \ldots \ldots \ldots \ldots \ldots 96$

Total names on list, Nov. $29,1911 \ldots \ldots \ldots \ldots \ldots \ldots \ldots \ldots \ldots, \overline{596}$

Paid up membership, Nov. 29, $1911 \ldots \ldots \ldots \ldots \ldots \ldots \ldots \ldots \ldots . \ldots 486$

Honorary membership, Nov, $29,1911 \ldots \ldots \ldots \ldots \ldots \ldots \ldots \ldots \ldots 7$

Delinquent, but kept on list as per constitution $\ldots \ldots \ldots \ldots \ldots \ldots .103$

JAMES F. MiLIIS, Secretary.

\section{MINUTES OF CHEMISTRY SECTION.}

Meeting called to order by Chairman Mr. F. B. Wade at 10:20 a. m. Report of nominating committee, given by $\mathrm{Mr}$. Wirick, the Chairman. Chairman, John W. Shepherd, Chicago Normal School; Vice-Chairman, C. B. Curtis, Central High School, St. Louis, Mo.; Secretary, Leon D. Judd, L,ockport, Ill.

Moved that the Secretary cast ballot for the persons named. Carried. Secretary cast the ballot. Paper by Dr. W. R. Smith on Night School Work in Chemistry.

Discussion participated in by Dr. A. L. Smith and Professor W. C. Hawthorne.

Second paper on "The Needs of the Community in Chemical Education as Seen in Y. M. C. A. Educational Work," was given by Mr. F. B. Emery, Chicago Central Y. M. C. A., who took the place of Mr. C. L. Ward of the same school. Discussed by W. R. Smith and C. M. Wirick. 16 in attendance.

Section adjourned, $11: 30$ a. m.

JoH C. Hésslek, Secretary Pro Tem.

\section{MINUTES OF THE MATHEMATICS SECTION.}

The Mathematics Section held two meetings at Lewis Institute, Friday and Saturday, December 1 and 2, 1911.

Friday afternoon session.-In the absence of the chairman, Mr. R. L. Short, Mr. Ira J. Condit, the vice-chairman, presided.

The secretary read a letter from Mr. Short explaining his absence.

A nominating committee was appointed as follows: Mr. W. Lee Jordan of Des Moines, Ia., chairman; Miss Esther Houser of Troy, Ohio; and $\mathrm{Mr}$. C. A. Petterson of Chicago.

The Report of Committee on Results, given by C. E. Comstock, of Peoria, Ill.. Mr. Comstock urged the necessity of scientific spirit in: daily work and scientific methods of testing the results. Two aspects of testing:

First: A teacher should have some means of ascertaining the extent of acquired knowledge or power. 
Second: Efficiency of a given method should be judged by comparison of results of different methods.

Under the first aspect was a consideration of the following aims for mathematics teaching:

Knowledge of the facts of Mathematics.

Acquisition of tools for future use.

Clear and concise expression of thought.

Clear perception of logic of relations.

Meaning of laws and operations in Algebra and of a proof in Geometry.

To fix power and habit of testing one's own work.

Abrlity to observe and to generalize, etc.

Some of the broader, more neglected aims are: Habits of study, of persistance, concentration, orderliness, of will and control; discovery of special talents; encouraging originality and initiative.

Second Aspect: Methods of testing results. Following the suggestions of Professor Thorndike, some ideas for scientifically constructed examinations were given; but a test should be on only one thing at a time, as memory, speed, use of best methods, accuracy, general information.

$$
\text { Eifficiency }=\frac{\text { attainment }}{\text { time }}
$$

Instead of ineffective discussion of many topics in mathematics, it is suggested that tests be made in an impartial scientific way, and a call is made for teachers willing to coöperate in this work.

Discussion of Report on Testing Results, by Charles Otterman, of Cincinnati, Ohio. In this discussion, Mr. Otterman brings out the idea that scientific testing requires an impartial mind measuring according to fixed standards. The wholly impartial attitude of mind will always be the ideal toward which a teacher should strive, but which no one will probably ever reach.

He shows also that the standards fixed by one teacher will vary from time to time; hence the best testing will be according to standards fixed, not by one's own experience, but by the experience of many.

In addition to the tests given in the report, several others in algebraic manipulations were given.

-The Applications of Mathematics to Problems of the Shop, by Kenneth G. Smith of the University of Wisconsin.

In this excellent paper, Professor Smith made it clear that he was discussing "Applied Shop" rather than "Applied Mathematics," from the standpoint of a teacher of apprentice boys and shop men in "Continuation Schools."

The shop man will learn or accept only that mathematics for which he sees his immediate need. He gets his application first and his principles afterwards. This is the essential difference between mathematics in a technical high school and the teaching of this subject to boys already employed in shops, who have a half-day per week or less to study.

Principles in selecting and presenting shop problems:

1. They must come from the shop. Good mathematics problems are not necessarily good shop problems.

2. They should be stated in shop terms.

3. Data should be given in accordance with shop usage and the results wobtained should represent good practice.

4. Problems should not be made unnecessarily complicated.

5. Do not confuse shop problems with problems of design.

6. Use the actual thing, when possible; if impossible, use sketches.

7. Use good shop sense in accuracy. of measurement. 
8. Take time to explain mechanical whys and wherefores, but not the mathematical whys, unless a boy is particularly interested in this subject.

On charts, Professor Smith outlined some shop topics especially applicable to the teaching of certain subjects in mathematics.

I. Common fractions:

1. Measuring scale.

2. Lengths of bolts and studs.

3. Cutting from bar stock.

4. Over-all dimensions.

5. Omitted dimensions.

II. Decimal fractions:

1. Micrometer.

2. Decimal equivalents.

3. Speeds, cuts, feeds, etc.

III. Percentage :

1. Composition of alloys and various kinds of steel.

2. Shop pay roll.

3. Wages.

IV. Areas and volumes:

1. Circumference and areas of circles.

2. Areas of rectangle, hexagon, octagon, triangle, and pentagon.

3. Volumes and weights of bar stock.

4. Contents of tanks.

V. Ratio and Proportion:

1. Speeds, pulleys, and gears.

VI. Handling of symbols, equations and formulae is necessary; also in Trigonometry, functions of angles and solution of triangles.

"The Significance of the Real Problem in Secondary Mathematics," was presented in a scholarly paper by Charles W. Newhall of Faribault, Minn. He showed how the very ancient problem of logical vs. practical mathematics had been discussed century after century by extremists on both sides; but the present tendency is toward a more conservative position, the finding of the proper balance between the cultural and the disciplinary values of mathematics, on the one hand, and the value of its practical applications on the other.

The reports of such committees as the one on College Entrance Requirements, the National Committee on Geometry Syllabus, and the Committee on Algebra Syllabus of the Middle States, all corroborate this view. Opinions of some of the leaders of mathematical thought were cited, showing:

First. That a uniform course in secondary mathematics is desirable in all our schools except those of a special class. The consensus of opinion seems to be that such a course should teach Algebra and Geometry for their own sake and as connected logical systems, but with a recognition of the practical value of their study.

Second. That the real problem has an important place in such a course. It should not be the underlying basis of mathematical instruction, nor its end or aim.

Miss Cleo Murtland of Wooster, Mass., was unable to be present to give her paper on "Problems for Girls."

Dr. H. R. Hedrick of the University of Missouri gave his discussion of the Report on Notation at this session. His suggestions are:

1. That notation should be as uniform as is consistent with proper teaching throughout the entire curriculum. 
2. That changes in notation should be made slowly.

3. That useless duplications should be avoided.

4. That colloquial phrases be recognized sparingly.

5. That suggestive notation be given the preference.

6. All definitions should be so worded that they may be capable of continuous development.

About 100 were present at the Friday afternoon session.

The assessment levied amounted to $\$ 17.70$.

\section{Saturday Morning Session}

The Report of the Committee on Uniform Notation, continued from 1910, was given by L. P. Jocelyn of Ann Arbor, Mich.

The committee recommends the series of digits be $0,1,-9$; not $1,-9,0$; that the symbol 0 be read zero; that decimal fractions be so called, not decimals; that in reading numbers "and" should not be used except at the decimal point; that in the four fundamental operations, the operator comes after the operand; that proportions be written as fractional equations.

The advisability of considering all fundamental operations as always performed on abstract numbers is discussed. The very careful reading of exponents and the elimination of obsolete symbols and terms are strongly urged.

Professor George R. Twiss of Ohio State University discussed the report from the Physics standpoint. He showed how many of the recommendations of this report have sound psychological foundation; especially the suggestion concerning the fundamental operations always being with abstract numbers.

He added some recommendations concerning uniform use and interpretation of certain terms and formulae in physics, and an agreement on single letters to represent each physical quantity, in both elementary and advanced physics.

He cautioned, however, that our decisions should not be so fixed and final that they stand in the way of further progress.

The last paper presented was one on "Correlation," by Miss Edith Long of Lincoln, Nebraska. At her own request, this paper will not be published.

Miss Long gave to each one present a synopsis of the "Course in Correlated Mathematics," which is being used in the Lincoln High School. This aims to fuse completely the two subjects of Algebra and Geometry.

In the discussion, it was brought out that in Lincoln and in Ann Arbor there is no mathematics in the first year, but a general science course is substituted.

The Report on Notation was not accepted, for the section felt the need of further discussion before taking any action. It was moved by $\mathrm{Mr}$. Newhall that the Committee be continued to consider uniform notation in Geometry, Trigonometry, and Advanced Algebra, also. The motion was seconded by Dr. Slaught. Mr. Petterson suggested that printed copies be sent to members one month in advance of the meeting. The suggestion was accepted and the motion was carried.

On a motion by Mr. Jocelyn the Committee on Results was continued with the suggestion that more experiments that can be used, be incorporated in the report.

The report of the nominating committee was as follows:

For Chairman, Mr. Ira Condit, State Teachers College, Cedar Falls, Iowa: for Vice-Chairman. Mr. Charles W. Newhall, Shattuck School. 
Faribault, Minn.; for Secretary, Miss Marie Gugle, Central High School, Toledo, Ohio.

On a motion by Mr. Hart the chairman of the committee cast the ballot for the above officers.

About 70 were present at the Saturday morning session.

Copies of the reports given may be had by applying to the chairman or the secretary.

\section{E. MarIE Gugle, Secretary.}

\section{Minutes of the Physics Section of the Central Association of Science}

\section{and Mathematics.}

The first session of the Physics Section was held in the Auditorium of Lewis Institute on Friday afternoon, December 1.

The first number of the program was in joint session with the Chemistry Section. The speaker, introduced by Chairman Frank B. Wade of the Chemistry Section, was Mr. L. A. Touzalin, assistant chief chemist of the Illinois Steel Works. His subject, "The Electric Furnace for Steel," was illustrated by lantern slides which showed characteristic views of the steel industry, from the ore mines in Minnesota, to the devices for refining and perfecting the steel, the latest example of which is the electric furnace. In the minutes of the Chemistry Section will be found an account of this important modern device. Chairman H. L. Terry then took charge of the program for the Physics Section, the Chemistry Section retiring. The chair appointed as a nominating committee: Mr. A. A. Upham, of Whitewater, Wis.; Mr. John P. Drake, Macomb, I1l., and Mr. F. R. Nichols, of Chicago.

After a brief historical review of the several "New Movements" in the teaching of high school physics by the chairman, a paper upon "The Results of New Movement in the Teaching of Physics" was read by Mr. G. A. Works, of Madison, Wis. This interesting and suggestive paper is printed in full in the Proceedings. In it is brought out the fact that the "New Movement" has caused teachers to test the efficiency of their methods and work, and has led to various educational experiments which aim at more effective work from the standpoint of the pupils' efficiency.

This paper aroused much interest and it was followed by an extended discussion led by Mr. G. O. Banting, Stoughton, Wis., who stated that one means of making the courses in science effective is to experiment and to publish the results. "We should interest the child more than at present."

J. W. Shepard spoke for social efficiency. "Would not limit the topics of study."

E. E. Burns: "I would introduce significant material. There is danger of swinging too far in the new movement."

G. R. Twiss: "We must appeal to the real interests of the child. Often too few connections are made between schoolroom habits and outside habits, schoolroom ideas and home ideas. A logical scheme in a study belongs to the end instead of the beginning of education."

A paper well worth the thoughtful study of every science teacher was read by Professor W. C. Bagley, of the University of Illinois. Its subject, "Testing for Efficiency of Work," will be published in the Proceedings, and is full of helpful ideas. "Measurement of mental content must be objective; we cannot measure subjective factors as such." "Dependable knowledge has a firm foundation in fundamental habits." Scores of apt quotations could be made from this paper. It aroused and stimulated 